\title{
Amidst COVID - 19 Pandemic: How to Gain Customer Advocacy for Indonesian Online Marketplaces Selling Luxury Products?
}

\author{
Ignatius Agus Suryono ${ }^{1}$, Aryono Yacobus ${ }^{1}$, Michelle Yoanna Franscisca Brigitta ${ }^{1}$ \\ 1Faculty of Economics, University of Pembangunan Nasional "Veteran" Yogyakarta, Indonesia
}

\begin{abstract}
Amidst the prolonged COVID - 19 Pandemic, Indonesian online marketplaces selling luxury brand products have been experienced a decrease in their market share, while on the other side, Indonesian online marketplaces selling standard products have been experienced a bullish position with their extraordinary increase of market share. In this research, we tried to examine the impact of brand satisfaction on customer advocacy with brand loyalty as both mediating and moderating variable and luxury brand attachment as mediating variable. Our focus in this research was on Indonesian marketplaces selling luxury brand products during this terrible pandemic, COVID - 19 Pandemic. We examined 108 customers who had purchasing experiences on luxury-brand sports shoes at Indonesian online marketplaces. In choosing our respondents, we used a non-probability sampling technique, the purposive sampling method. To analyze our hypothesis, we used a qualitative approach, which is path analysis. The results show that luxury brand attachment has a significant positive effect on brand loyalty, brand loyalty has a significant positive effect on customer advocacy, both mediated by brand loyalty and luxury brand attachment, and brand loyalty strengthens the impact of luxury brand attachment on customer advocacy. From that findings, we suggest that Indonesian online marketplaces that sell luxury brand products should increase their brand satisfaction through customer loyalty and luxury brand attachment to gain higher customer advocacy during and post COVID - 19 pandemic
\end{abstract}

Keywords: customer advocacy, luxury brand attachment, brand loyalty, brand satisfaction

\section{INTRODUCTION}

The COVID 19 pandemic has created some increases in marketplaces, especially marketplaces selling common goods with regular brands that targeting middle-lower income customers. A market share increase of up to $480 \%$ has made those marketplaces become the leader in their market share (Michelle Natalia, Journalist, Monday 05 October 2020 15:48 WIB (economy.okezone.com, 2020). A similar condition is not felt by marketplaces selling luxury brand products. In Indonesia, in the fourth quarter of 2020 , the impact of the covid19 pandemic has declined the market share of the luxury brand marketplaces (price. co.id, 2021). Switching to another marketplace is easier to do by consumers in the 4.0 digital marketing era. The ease of finding all information on various products and brands through The Internet becomes the reason (Karyono et al., 2020). As Pahlavi (2017) said, by the time gone, The increase of the form and the number of e-commerce will resulting in fierce competition.

The decline in market share for the luxury brand marketplace in the Indonesian online market had drawn the authors' attention to provide a solution from an academic perspective for the problem faced by the Indonesian luxury-brand marketplace through this research. The initial observations found that there are various brands of sports shoes that exist in the Indonesian market, both online and offline market. 
Those brands could be categorized into two types which are the original brand and the unoriginal brand. This research focuses on original sports shoes.

Consumer advocacy is more relevant to luxury brands for several reasons (AS Shimul, I. Phau, 2018). First, according to Phau and Prendergast (2000), luxury brand consumers seek information about the producer and other consumer experiences in evaluating luxury brands. Phau and Prendergast (2000) emphasize that consumer advocacy plays an important role in purchasing decisions of luxury consumers. Second, as stated by Klein et al. (2016), both consumers and customers are the sources of information that are considered more reliable by consumers than corporate messages generated for marketing purposes. The concept of advocacy from consumers and customers is expected to be more relevant for luxury brand consumers. Third, based on Schneider (2017), affluent consumers tend to change brands frequently and tend not to have brand loyalty.

Nueno and Quelch (1998) defined a luxury brand as a product or service that goes beyond its functionality and emphasizing individual status and image. Compared to daily necessity products, a luxury product often gives more emphasis on the owner's image rather than its objective physical attributes. An important reason for someone to own a luxury product is to demonstrate their success and their social status and to provide confidence (KPMG, 2006).

\section{Research Objectives}

The objective of this research was to measure and analyze the impact of luxury brand attachment on customer advocacy.

\section{LITERATURE REVIEW}

\section{Customer Advocacy}

Kotler et al. (2016) said that several companies had been established with a business model that is suitable for customers to share their experiences with others, and customer advocacy has been proved as a strategy that gives a competitive advantage over the years. The internet of things in nowadays situation allows customers to express opinions that can be heard by others. Customer Advocacy can change a customer's mindset and realize that a stranger's advice (as fellow consumers) may be more credible than a recommendation from a celebrity endorser. Thus, the internet of things creates the perfect environment for customer advocacy towards brands (Kotler et al., 2017). There are two customer advocacy perspectives, the company perspective, and the customer perspective. Based on the customer's perspective, customer advocacy is a series of actions resulted from taking the customer's point of view in serving consumers or treating the customer in the desired way (from the consumer perspective).

\section{Brand Loyalty}

Many marketing studies have identified brand loyalty as the primary outcome of strong customerbrand relationships (Aksoy et al., 2015; Chaudhuri and Holbrook, 2001; Dick and Basu, 1994). Krishnan (1996) said that brand loyalty could be built by developing and strengthening brand memories in three main ways: exposure to marketing communications, word of mouth, and direct personal experience. Some studies showed that customers in a happy mood tend to adopt top-down processing (Bodenhausen, Kramer, \& Süsser, 1994). When making purchasing decisions, happy customers are more likely to rely on stereotypical brand information than sad customers (Adaval, 2001). Therefore, customers with higher affective product brand loyalty are more likely to draw stereotyped conclusions and form impressions about the product or service category. 


\section{Brand Satisfaction}

According to Zeithaml et al. (2017), satisfaction is the customer's evaluation of a product or service in terms of whether the product or service is met customer needs and expectations or not. The failure to meet consumers' needs and expectations result in product or service dissatisfaction. Brand satisfaction is a result of post-purchase customer emotional responses through comparing the expected quality with perceived quality (Oliver, 1980). The customer's desire to extend its relationship with a satisfying brand generates some behavioral intentions, including brand loyalty, positive word of mouth, and customer advocacy. In addition, the rate of "satisfied" develops strong cognitive and affective bonds with the brand where they consider the brand as an integral part of their lives (Belaid and Behi, 2011).

\section{Luxury Brand Attachment}

There are a number of studies on luxury brands that examine the relationship between a luxury brand with premium prices and the consumption behavior of people seeking prestige (Vigneron and Johnson, 2004). Luxury brands are defined as going beyond functionality and emphasizing individual status and image (Nueno and Quelch, 1998). These reasons suggest that luxury brands provide individuals with more non-functional benefits and personal images than necessities brands. Luxury is "the emotional bond that connects the customer with the luxury brand and develops the customer's deep feelings towards the luxury brand" (Shimul et al., 2016). The luxury needs of customers for exclusivity, beauty as well as the joy and pleasure obtained from luxury brands strengthen the strong emotional bond between the customer and a brand (Kim and Joung, 2016).

\section{Research Framework}

The framework of this study refers to AS Shimul, I. Phau (2018). In this study, the Indonesian online marketplaces selling luxury brands of sports shoe weres examined.

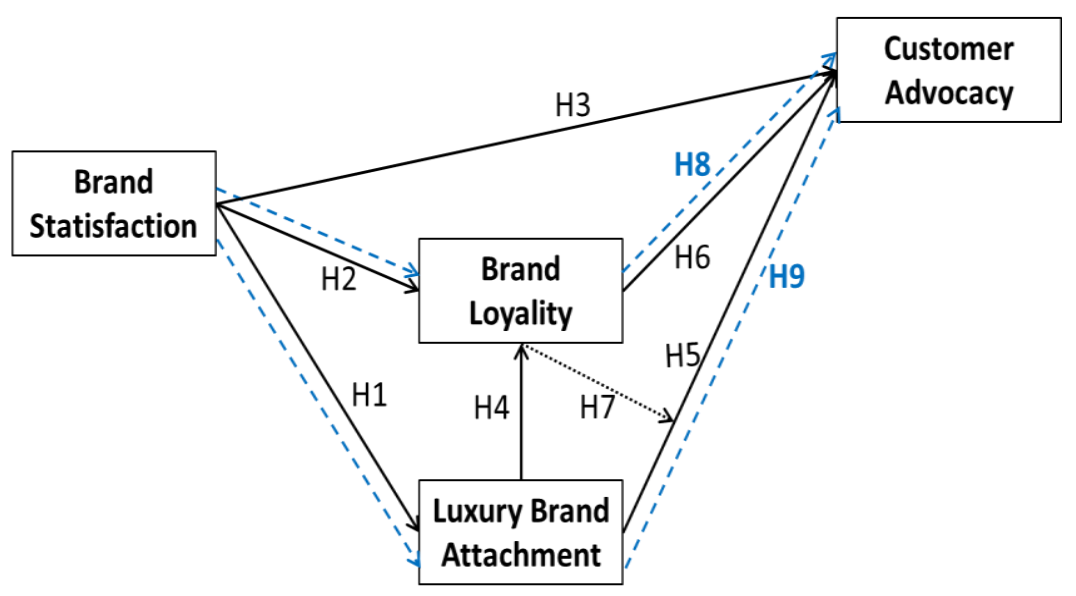

.Figure 1: Framework for research

\section{RESEARCH METHOD}

The population and the sample in this study were the customers of Indonesian online marketplaces selling luxury brands of sports shoes who had made four-time purchases. The respondents were taken by non-probability sampling technique, purposive sampling method (Sugiyono, 2017). We succeed in collecting 108 data. A quantitative hypothesis analysis was used to investigate the impact of brand 
RSF Conference Series: Business, Management and Social Sciences, Vol. 1 (3), 199-210

Amidst COVID - 19 Pandemic: How to Gain Customer Advocacy for Indonesian Online Marketplaces Selling Luxury Products?

Ignatius Agus Suryono, Aryono Yacobus, Michelle Yoanna Franscisca Brigitta

satisfaction on customer advocacy as well as the moderating and mediating impact of luxury brand attachment and brand loyalty on the relation.

\section{FINDINGS AND DISCUSSION}

\section{The Result of Hypothesis H1 Testing}

The collected data were analyzed using SPS 24 (Ghozali, 2018). A significant positive result (hypothesis $\mathrm{H} 1$ is accepted) with multiple linear regression equation Int $=0.376+0.789 \mathrm{BS}$ and an $\mathrm{r}$ square score as big as 0.639 (63.9\%) was obtained from hypothesis $\mathrm{H1}$ testing. This result is in line with AS Shimul, I. Phau (2018). From the SPSS outputs can be concluded that brand satisfaction has a big impact on luxury brand attachment.

Table 1. Coefficients Effect of Brand Satisfaction on Luxury Brand

\begin{tabular}{|c|c|c|c|c|c|c|}
\hline \multicolumn{7}{|c|}{ Engagement Coefficients ${ }^{a}$} \\
\hline & \multirow[t]{2}{*}{ Model } & \multicolumn{2}{|c|}{$\begin{array}{l}\text { Unstandardized } \\
\text { Coefficients }\end{array}$} & \multirow{2}{*}{$\begin{array}{c}\text { Standardized } \\
\text { Coefficients } \\
\text { Beta }\end{array}$} & \multirow[t]{2}{*}{$\mathrm{t}$} & \multirow[t]{2}{*}{ Sig. } \\
\hline & & B & Std. Error & & & \\
\hline \multirow[t]{2}{*}{1} & (Constant) & 0.376 & 0.362 & & 1.040 & 0.300 \\
\hline & $\begin{array}{l}\text { Brand } \\
\text { Satisfaction (BS) }\end{array}$ & 0.789 & 0.093 & 0.637 & 8.516 & 0.000 \\
\hline
\end{tabular}

These results show us that the customers of luxury-branded sports shoes feel excited and fully satisfied, which emerging their engagement to always wear luxury-brand sport shoes.

\section{The Result of Hypothesis $\mathrm{H} 2$ and $\mathrm{H} 4$ Testing}

The result of hypotheses $\mathrm{H} 2$ and $\mathrm{H} 4$ testing show that both brand satisfaction and luxury brand attachment have a significant positive impact on brand loyalty (hypotheses $\mathrm{H} 2$ and $\mathrm{H} 4$ are accepted). From the SPSS output on Table 2, can be seen the multiple linear regression as follows, CT $=0.032+$ $0.707 \mathrm{BS}+0.312 \mathrm{BA}$. The adjusted R square score of $0.668(66.8 \%)$ was also obtained from the SPSS output

Table 2. Coefficients Effect of Brand Satisfaction Luxury Brand Attachment on Brand Loyalty

\begin{tabular}{|c|c|c|c|c|c|c|}
\hline \multicolumn{7}{|c|}{ Coefficients } \\
\hline & \multirow[t]{2}{*}{ Model } & \multicolumn{2}{|c|}{$\begin{array}{l}\text { Unstandardized } \\
\text { Coefficients }\end{array}$} & \multirow{2}{*}{$\begin{array}{c}\begin{array}{c}\text { Standardized } \\
\text { Coefficients }\end{array} \\
\text { Beta } \\
\end{array}$} & \multirow[t]{2}{*}{$\mathrm{t}$} & \multirow[t]{2}{*}{ Sig. } \\
\hline & & B & Std. Error & & & \\
\hline \multirow[t]{3}{*}{1} & (Constant) & 0.032 & 0.266 & & 0.120 & 0.904 \\
\hline & $\begin{array}{l}\text { Brand } \\
\text { Satisfaction } \\
8.040\end{array}$ & 0.707 & 0.88 & 0.581 & (BS) & 0.000 \\
\hline & $\begin{array}{l}\text { Luxury Brand } \\
\text { Attachment } \\
0.3184 .392\end{array}$ & 0.312 & 0.71 & & (LBA) & 0.000 \\
\hline
\end{tabular}


From these results, we can say that customers who buy a luxury-branded sports shoe feel very excited and fully satisfied about the luxury-brand performance, which allows the emerging of positive emotions which create a little brand attachment which leads to loyalty.

\section{The Result of Hypothesis H3, H5, and H6 Testing}

The SPSS outputs for $\mathrm{H} 3, \mathrm{H} 4$, and $\mathrm{H} 6$ hypothesis testing show a positive impact, but the only one that has a significant effect is Hypothesis H6, while the others only have a little impact (insignificant). In other words, brand satisfaction and luxury brand attachment have an insignificant positive effect on customer advocacy, while brand loyalty has a significant positive impact on customer advocacy (hypotheses $\mathrm{H} 3$ and $\mathrm{H} 5$ are rejected, while hypothesis $\mathrm{H} 6$ is accepted).

Table 3. Coefficients The effect of brand satisfaction, luxury brand attachment, and brand loyalty on customer advocacy

\begin{tabular}{|c|c|c|c|c|c|}
\hline \multicolumn{6}{|c|}{ Coefficients } \\
\hline \multirow[t]{2}{*}{ Model } & \multicolumn{2}{|c|}{$\begin{array}{l}\text { Unstandardized } \\
\text { Coefficients }\end{array}$} & \multirow{2}{*}{$\begin{array}{c}\begin{array}{c}\text { Standardized } \\
\text { Coefficients }\end{array} \\
\text { Beta }\end{array}$} & \multirow[t]{2}{*}{$\mathrm{t}$} & \multirow{2}{*}{ Sig. } \\
\hline & $\mathrm{B}$ & Std. Error & & & \\
\hline 1 (Constant) & 1.120 & 0.361 & & 3.104 & 0.002 \\
\hline $\begin{array}{l}\text { Brand Satisfaction } \\
\text { (BS) H3 }\end{array}$ & 0.107 & 0.152 & 0.089 & 0.704 & 0.438 \\
\hline $\begin{array}{l}\text { Brand Loyalty } \\
0.4530 .4603 .422\end{array}$ & & 0.132 & & (BL) & 0.001 \\
\hline $\begin{array}{l}\text { Luxury Brand } \\
\text { Attachment (BSA) } \\
\text { H5 }\end{array}$ & 0.116 & 0.105 & 0.120 & 1.110 & 0.269 \\
\hline
\end{tabular}

The multiple linear regression equation for Hypotheses $\mathrm{H} 3, \mathrm{H} 4$, and $\mathrm{H} 6$ is as follows, $\mathrm{CA}=1.120+$ $0.107 \mathrm{BS}+0.453 \mathrm{BL}+0.116 \mathrm{LBA}$. The adjusted R square score is 0.307 (30.7\%). Both Hypotheses H3 and H5 have a different result AS Shimul, I. Phau (2018), while the Hypothesis H6 result is in line with AS Shimul, I. Phau (2018). This result depicts that Indonesian online marketplaces have been able to create customer advocacy. From those results, we can conclude that customers who buy a luxury-branded sports shoe feel less satisfied and don't want to share their experience with others. In other words, they don't create customer advocacy on luxury-branded they bought. As well as luxury brand attachment, it can't evoke customer emotions to share their experiences with others, so they can't have any impact on customer advocacy. These are possibly caused by social restriction policy applied during the COVID-19 pandemic, but consumer loyalty can encouraging consumers to share their experiences with others, so they can have some impact on customer advocacy. Even during this covid19 pandemic, being consistent between brand satisfaction and brand loyalty will encourage customer advocacy. The research on the three variables above shows that the marketing communication design strategy during the COVID-19 pandemic must be prioritized on the performance of luxury brands to build brand loyalty, and customer advocacy will be built. 
RSF Conference Series: Business, Management and Social Sciences, Vol. 1 (3), 199-210

Amidst COVID - 19 Pandemic: How to Gain Customer Advocacy for Indonesian Online Marketplaces Selling Luxury Products?

Ignatius Agus Suryono, Aryono Yacobus, Michelle Yoanna Franscisca Brigitta

\section{The Result of Hypothesis $\mathrm{H} 7$ Testing}

The results of testing indicate that brand loyalty moderates positively and significantly between the two sub-influences of luxury brand attachment on customer advocacy (hypothesis H7 is accepted).

\section{Moderated Regression Analysis (MRA) Testing}

The interaction test can be seen in Table 4. Based on the results of the regression test in Table 4, the following equation can be formulated:

$$
\mathrm{CAY}=2.976-0.359 \mathrm{X}+0.143 \mathrm{X}^{*} \mathrm{M}
$$

Table 4. Results of Analysis of the Effect of Luxury Brand Attachment on customer advocacy mediated by Brand Loyalty

\begin{tabular}{|c|c|c|c|c|c|}
\hline \multirow{2}{*}{ Model } & \multicolumn{7}{|c|}{$\begin{array}{c}\text { Unstandardized } \\
\text { Coefficients }\end{array}$} & $\begin{array}{c}\text { Standardized } \\
\text { Coefficients }\end{array}$ & \multirow{2}{*}{ T } & \multirow{2}{*}{ Sig. } \\
\cline { 2 - 5 } & $\mathrm{B}$ & $\begin{array}{c}\text { Std. } \\
\text { Error }\end{array}$ & Beta & & \\
\hline 1 (Constant) & 2.976 & 0.334 & & 8916 & 0,000 \\
\hline $\begin{array}{c}\text { Luxury Brand } \\
\text { Attachment (BSA) X }\end{array}$ & -0.359 & 0.198 &,- 370 & -1.813 & 0.073 \\
\hline $\begin{array}{l}\text { Interaction * Brand } \\
\text { Loyalty (BL) M }\end{array}$ & 0.143 & 0.031 & 0.934 & 4.572 & 0.000 \\
\hline \multicolumn{2}{|l|}{ a. Dependent Variable: TOTAL_CAY } & & & & \\
\hline
\end{tabular}

Based on the results of the regression test, the following equation can be formulated:

$$
\mathrm{CAY}=2.976-0.359 \mathrm{X}+0.143 \mathrm{X} * \mathrm{M}
$$

From these results, it can be concluded that Brand Loyalty moderates positively and significantly in the impact of luxury brand attachment on customer advocacy. This result is not in line with the research of AS Shimul, I. Phau, 2018. The results indicate that there is a positive moderating effect of brand loyalty on the two sub-relationships of luxury brand attachment and customer advocacy. In other words, brand loyalty will strengthen the influence of Luxury brand attachment on customer advocacy. The discussion of this study shows that customers who buy luxury-brand sports shoes have loyalty to the luxury brand they buy and are able to encourage these customers to recommend to new consumers and other customers so as to strengthen the influence between luxury brand attachment to customer advocacy, it is also consistent between satisfaction brand and brand loyalty will strengthen the influence of luxury brand attachment to customer advocacy. The research on the three variables above shows that marketing communication design strategies during the COVID-19 pandemic must be prioritized on brand performance to form luxury brand loyalty, and customer advocacy will be built.

\section{The Result of Hypothesis H8 Testing}

The Hypothesis H8 testing result is brand loyalty mediates the positive and significant effect of brand satisfaction on customer advocacy (hypothesis H8 is accepted). The equations are shown in the following equations:

$$
\begin{aligned}
& \mathrm{BL}=\alpha+\mathrm{P} 2 \mathrm{BS}+\mathrm{e} 1 \\
& \mathrm{CA}=\alpha+\mathrm{P} 2 \mathrm{BS}+\mathrm{P} 6 \mathrm{BL}+\mathrm{e} 2
\end{aligned}
$$


RSF Conference Series: Business, Management and Social Sciences, Vol. 1 (3), 199-210

Amidst COVID - 19 Pandemic: How to Gain Customer Advocacy for Indonesian Online Marketplaces Selling Luxury Products?

Ignatius Agus Suryono, Aryono Yacobus, Michelle Yoanna Franscisca Brigitta

\section{Simple Linear Regression for Equation 1}

Table 5a. Coefficients Effect of Brand Satisfaction on Brand Loyalty

\begin{tabular}{|c|c|c|c|c|c|}
\hline \multicolumn{6}{|c|}{ Coefficients } \\
\hline \multirow[b]{2}{*}{ Model } & \multicolumn{2}{|c|}{$\begin{array}{c}\text { Unstandardized } \\
\text { Coefficients }\end{array}$} & \multirow{2}{*}{$\begin{array}{c}\text { Standardized } \\
\text { Coefficients } \\
\text { Beta }\end{array}$} & \multirow[b]{2}{*}{$\mathrm{t}$} & \multirow[b]{2}{*}{ Sig. } \\
\hline & B & $\begin{array}{l}\text { Std. } \\
\text { Error }\end{array}$ & & & \\
\hline 1 (Constant) & 0.150 & 0.287 & & ,522 & 0.603 \\
\hline Brand Satisfaction (BS) & 0.953 & 0.073 & 0.784 & 12.991 & 0.000 \\
\hline
\end{tabular}

The SPSS output above shows that the unstandardized beta brand satisfaction (BS) value is 0.953 and is significant at 0.000 . The standard error value is 0.287 . This means that brand satisfaction has a direct and significant effect on Brand Loyalty.

\section{Multiple Linear Regression for Equation 2}

Table 5b. Coefficients Effect of Brand Satisfaction and Luxury Brand Attachment to Customer Advocacy

\begin{tabular}{|c|c|c|c|c|c|}
\hline \multicolumn{6}{|c|}{ Coefficients } \\
\hline \multirow[b]{2}{*}{ Model } & \multicolumn{2}{|c|}{$\begin{array}{l}\text { Unstandardized } \\
\text { Coefficients }\end{array}$} & \multirow{2}{*}{$\begin{array}{c}\begin{array}{c}\text { Standardized } \\
\text { Coefficients }\end{array} \\
\text { Beta }\end{array}$} & \multirow[b]{2}{*}{$\mathrm{t}$} & \multirow[b]{2}{*}{ Sig. } \\
\hline & B & $\begin{array}{l}\text { Std. } \\
\text { Error }\end{array}$ & & & \\
\hline 1 (Constant) & 1,155 & 0.360 & & 3,211 & 0.002 \\
\hline Brand Satisfaction (BS) & 0.143 & 0.148 & 0.120 & 0.968 & 0.335 \\
\hline Brand Loyalty (BL) & 0.511 & 0.122 & 0.519 & 4,195 & 0.000 \\
\hline
\end{tabular}

SPSS output for Equation 2 shows an unstandardized beta value for brand satisfaction (BS) of 0.143 with a significance value of 0.335 (greater than 0.05 ), so it doesn't meet the signature requirements. The standard error value is 0.148 . For brand loyalty (BL), the value of unstandardized beta is 0.511 with a significance value of 0.000 (less than 0.05 ), so it met the significance requirements, with the standard error value of 0.122 .

\section{Path Analysis Model}

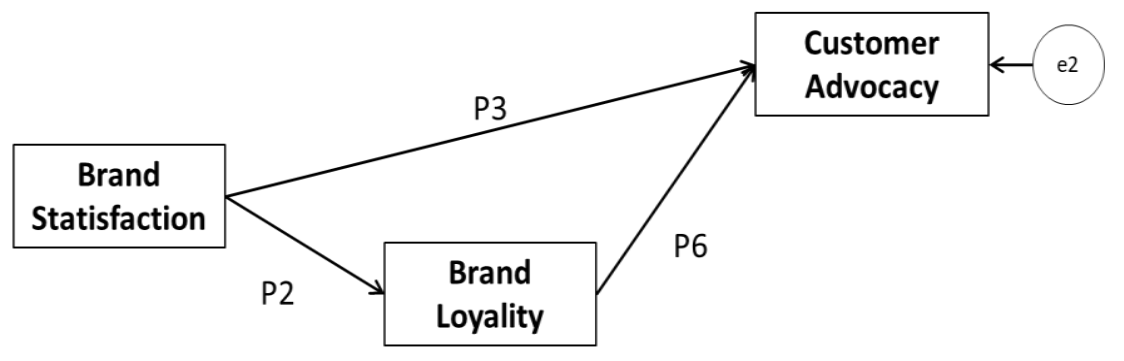

Figure 2. Path Analysis Model(PathAnalysis) 
The model above shows the regression model of the first and second equations that form a path analysis model with the customer trust variable as a mediator. The value of the mediating variable can be generated by the Sobel test using the Calculator: Sobel Test For The Significance Of Mediation 4.0, www.danielsoper.com as follows:

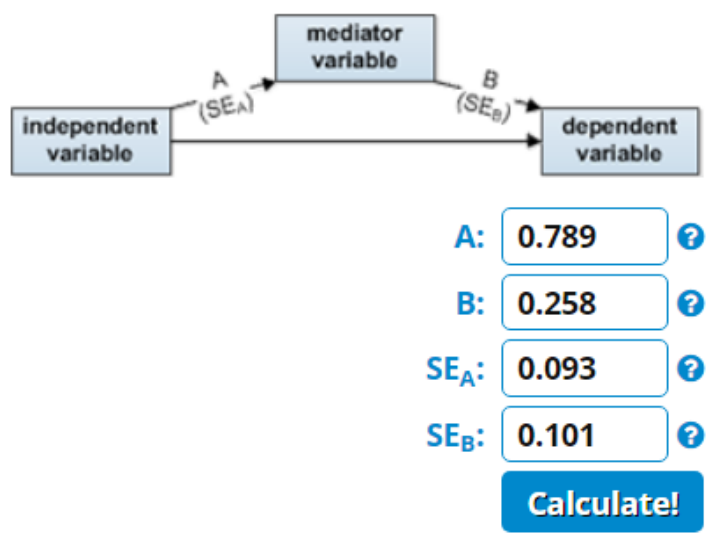

Sobel test statistic: $\mathbf{2 . 4 4 5 9 8 5 8 3}$

Figure 3. Sobel Test For The Significance Of Mediation 4.0

The calculation of the Sobel test above shows a $\mathrm{z}$ value of 2.446 , and this value is greater than 1.96 with a significance level of 0.05 . So it can be said that there is a mediating effect, so luxury brand attachment mediates the positive and significant effect of brand satisfaction on customer advocacy. These results are in line with research conducted by AS Shimul, I. Phau (2018). The discussion of this study shows that customers who buy luxury-brand sports shoes feel the pleasure of high satisfaction with the performance of luxury brands and create a desire to share experiences by conveying to consumers and other customers, causing high customer advocacy directly. Brand loyalty to the luxury brand can mediate the indirect effect of brand satisfaction on customer advocacy, but the amount of mediation is smaller than the direct influence, so the implications of the results of this research subsection provide a strategic concept of building a marketplace marketing communication design that sells luxury-brand sports shoes. Emphasizing the most important brand performance in order to cause customer advocacy can also highlight the design of brand loyalty marketing communications.

\section{The Result of Hypothesis H9 Testing}

The results of Hypothesis $\mathrm{H} 9$ testing shows that brand satisfaction has a positive and significant effect on customer advocacy and is mediated by luxury brand loyalty (hypothesis H8 is accepted). The equation can be seen in Equation 1 and Equation 2.

$$
\begin{aligned}
& \mathrm{LBA}=\alpha+\mathrm{P} 1 \mathrm{BS}+\mathrm{e} 1 \\
& \mathrm{CA}=\alpha+\mathrm{P} 3 \mathrm{BS}+\mathrm{P} 5 \mathrm{LBA}+\mathrm{e} 2
\end{aligned}
$$


RSF Conference Series: Business, Management and Social Sciences, Vol. 1 (3), 199-210

Amidst COVID - 19 Pandemic: How to Gain Customer Advocacy for Indonesian Online Marketplaces Selling Luxury Products?

Ignatius Agus Suryono, Aryono Yacobus, Michelle Yoanna Franscisca Brigitta

\section{Simple Linear Regression for Equation 1}

Table 6a. Coefficients Effect of Brand Satisfaction on Luxury Brand Attachment

\begin{tabular}{|c|c|c|c|c|c|}
\hline \multicolumn{6}{|c|}{ Coefficients } \\
\hline \multirow[b]{2}{*}{ Model } & \multicolumn{2}{|c|}{$\begin{array}{c}\text { Unstandardized } \\
\text { Coefficients }\end{array}$} & \multirow{2}{*}{$\begin{array}{c}\begin{array}{c}\text { Standardized } \\
\text { Coefficients }\end{array} \\
\text { Beta }\end{array}$} & \multirow[b]{2}{*}{$\mathrm{t}$} & \multirow[b]{2}{*}{ Sig. } \\
\hline & B & $\begin{array}{l}\text { Std. } \\
\text { Error }\end{array}$ & & & \\
\hline 1 (Constant) & 0.376 & 0.362 & & 1.040 & 0.300 \\
\hline Brand Satisfaction (BS) & 0.789 & 0.093 & 0.637 & 8.516 & 0.000 \\
\hline
\end{tabular}

The SPSS output above shows that the value of unstandardized beta of brand satisfaction (BS) is 0.789 and is significant at 0.000 . The resulting standard error value is 0.093 . This means that brand satisfaction has a direct and significant effect on luxury brand attachment.

\section{Multiple Linear Regression for Equation 2}

Table 6b. Coefficients Effect of Brand Satisfaction and Luxury Brand Attachment on Customer Advocacy

\begin{tabular}{|c|c|c|c|c|c|}
\hline \multicolumn{6}{|c|}{ Coefficients } \\
\hline \multirow[b]{2}{*}{ Model } & \multicolumn{2}{|c|}{$\begin{array}{l}\text { Unstandardized } \\
\text { Coefficients }\end{array}$} & \multirow{2}{*}{$\begin{array}{c}\begin{array}{c}\text { Standardized } \\
\text { Coefficients }\end{array} \\
\text { Beta }\end{array}$} & \multirow[b]{2}{*}{$\mathrm{t}$} & \multirow[b]{2}{*}{ Sig. } \\
\hline & B & $\begin{array}{l}\text { Std. } \\
\text { Error }\end{array}$ & & & \\
\hline 1 (Constant) & 1.135 & 0.379 & & 2.996 & 0.003 \\
\hline $\begin{array}{l}\text { Brand Satisfaction } \\
0.3563 .411\end{array}$ & 0.427 & 0.125 & & (BS) & 0.001 \\
\hline $\begin{array}{l}\text { Luxury Brand } \\
\text { Attachment } \\
0.1012 .548\end{array}$ & 0.258 & & 0.266 & (LBA) & 0.012 \\
\hline
\end{tabular}

The SPSS output for Equation 2 shows an unstandardized beta value for brand satisfaction (BS) of 0.427 with a significance value of 0.001 (less than 0.05 ). This fulfills the significance requirements, with the standard error value of 0.125 .

For luxury brand attachments, the unstandardized beta value is 0.258 with a significance value of 0.012 (less than 0.05 ). This fulfills the significance requirements, with the standard error value of 0.101 . 


\section{Path Analysis Model}

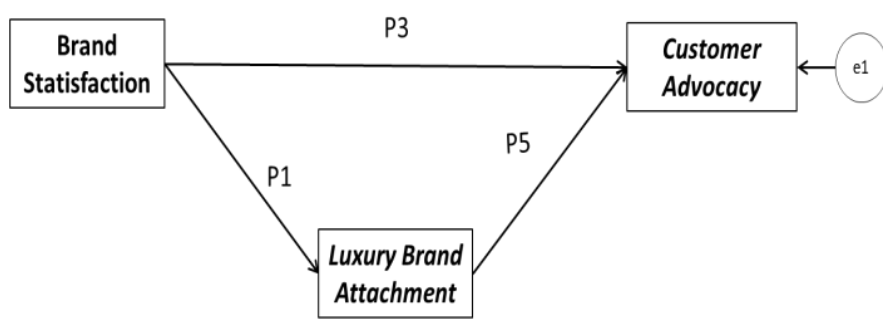

Figure 4. Path Analysis Model(PathAnalysis)

The model shown in Figure 4 shows the regression results of the first and second equations that form a path analysis model with brand loyalty as a mediator. The value of the mediating variable can be generated by the Sobel test using the Calculator: Sobel Test for The Significance Of Mediation 4.0, www.danielsoper.com as follows:

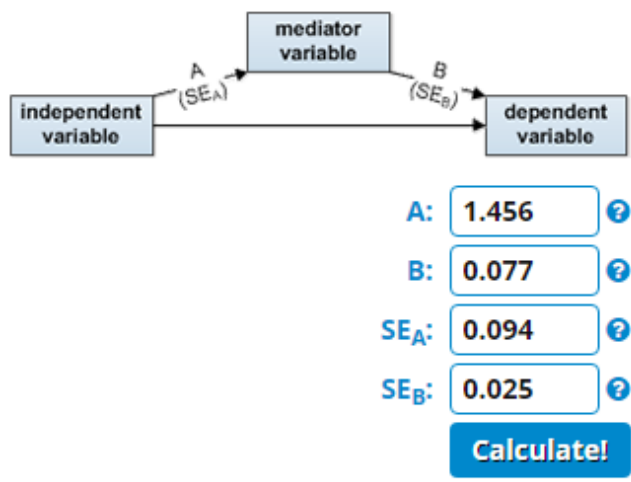

Sobel test statistic: $\mathbf{3 . 0 2 0 8 5 6 9 3}$

Figure 5. Sobel Test for The Significance Of Mediation 4.0

The calculation of the Sobel test above shows a z value of 3.020. This value is greater than 1.96 , with a significance level of 0.05 . Thus, it can be said that there is a mediating effect, so brand loyalty mediates the positive and significant effect of brand satisfaction on customer advocacy. These results are in line with research conducted by AS Shimul, I. Phau (2018).

The discussion of this study shows that customers who buy luxury-brand sports shoes feel the pleasure of high satisfaction with the performance of luxury brands and create a desire to share experiences by conveying to consumers and other customers, causing high customer advocacy directly. Customer attachment to the luxury brand also mediates the indirect effect of brand satisfaction on customer advocacy, so the implications of the results of this research subsection provide the concept of a design strategy to build a marketing communication marketplace that sells luxury-brand sports shoes, which must emphasize the performance of the brand, most importantly, also highlight the design. Luxury brand engagement marketing communication, the combination of the marketing communication design of these two variables will have an influence on the creation of customer advocacy on the customer's self to new consumers and customers. 


\section{CONCLUSION}

The conclusion of this research is that even during the covid19 pandemic, luxury brand brands, especially luxury-brand sports shoes, are marketing communication designs created by marketplaces and the luxury brand shoemaking industry along with shoe brand designs, brand performance is able to encourage the creation of effective customer advocacy to build customer advocacy for the marketplace, which sells luxury-brand sports shoes in the Indonesian online market. This research also produces one main strategy that can be implemented in tight competition 4.0, namely the design of marketing communications must be able to highlight brand performance, brand design according to the target market so that it can cause positive emotions to form customer advocacy.

Further research can be carried out with different types of luxury brand goods, a comparison of several luxury brands.

\section{ACKNOWLEDGEMENT}

The authors would like to thank the Institute for Research and Community Service, Universitas Pembangunan Nasional Veterans Yogyakarta, Indonesia, which has provided financial support for this research.

\section{REFERENCES}

Adaval, R. (2001). Sometimes it just feels right: The differential weighting of affect-consistent and affect-inconsistent product information. Journal of Consumer Research, 28(1), 1-17.

Aksoy, L., Keiningham, T.L., Buoye, A., Larivière, B., Williams, L., Wilson, I., 2015. Does loyalty span domains? Examining the relationship between consumer loyalty, other loyalties and happiness. J. Bus. Res. 68, 2464-2476.https://doi.org/10.1016/j.jbusres. 2015.06.033 .

A.S. Shimul, I. Phau, Consumer advocacy for luxury brands, Australasian Marketing Journal (2018),

Belaid, S., Temessek Behi, A., 2011. The role of attachment in building consumer-brand relationships: an empirical investigation in the utilitarian consumption context, J. Prod. Brand Manag. 20, 37-47. https://doi.org/10.1108/10610421111108003.

Chaudhuri, A., Holbrook, M.B., 2001. The chain of effects from brand trust and brand affect to brand performance: the role of brand loyalty, Brand 65, 81-93. https: //doi.org/10.1509/jmkg.65.2.81.18255

Dick, A.S., Basu, K., 1994. Customer loyalty: towards an integrated conceptual frame- work. J. Acad. Mark. Sci. 22, 99-113. https://doi.org/10.1177/0 0920703942220 01.

Ghozali, Imam. 2018. Aplikasi Analisis Multivariate dengan Program IBM SPSS 25 Edisi 9, Semarang, Badan Penerbit Universitas Diponegoro.

https://economy.okezone.com/read/2020/10/05/455/2288689/penjualan-online-naik-480selama-pandemi-covid-19.

https-iprice.co.id-insights-mapofecom-merce-February-2021

Karyono, Ign. Agus Suryono, Michael Alfonsus Liquori Suryo Sutrisno, 2020, Strategies In Dealing With Online Taxi Invasion To The Local Companies' Offline Minibus Taxi In Yogyakarta, Russian Journal of Agricultural and Socio-Economic Sciences (RJOAS), issue 2(98) of Feberuary 2020.

Klein, J.F., Falk, T., Esch, F.R., Gloukhovtsev, A., 2016. Linking pop-up brand stores to brand experience and word of mouth: the case of luxury retail. J. Bus. Res. 69, 5761-5767. https://doi.org/10.1016/j.jbusres.2016.04.172 .

Kotler, P., Armstrong, G., 2016, Principles of Marketing, 16th edition. New Jersey : Pearson Education, Inc. 
Kotler, P., Kartajaya H., Setiawan, I. (2017). Marketing 4.0 : moving from traditional to digital, John Wiley \& Sons, Inc., Hoboken, New Jersey.

Kim, J., Joung, H.-M., 2016, Psychological underpinnings of luxury brand goods repurchase intentions: brand-self congruity, emotional attachment, and perceived level of investment made, J. Glob. Sch. Mark. Sci. 9159, 1-16. https://doi.org/10.1080/21639159.2016.1174542.

KPMG (2006), "Luxury mereks in China”, available at: www.kpmg.fi/ (accessed 18 March 2011)

Krishnan H.S., 1996, Characteristics of memory associations: A consumer-based brand equity perspective, International Journal of Research in Marketing, Volume 13, Issue 4.

Nueno, J.L. and Quelch, J.A. 1998, The mass marketing of luxury, Business Horizons, Vol. 41 No. 6, pp. 61-70.

Oliver, R. L., 1980, A Cognitive Model of the Antecedents and Consequences of Statification Decisions.Journal of Marketing Research, 17(4), 460.doi:10.2307/3150499.

Pahlevi. 2017. Pengertian Marketplace dan Jenis-jenisMarketplace. https://www. pahlevi.net/pengertian-marketplace. (7 Oktober 2019).

Phau, I., Prendergast, G., 2000, Consuming luxury brands: the relevance of the "rar- ity principle, J. Brand Manag. 8, 122-138. https://doi.org/10.1057/ palgrave.bm. 2540013.

Schneider, H., 2017. Luxury brands require a different class of loyalty pro- gram [WWW document]. http://www.cmo. com/opinion/articles/2017/2/2/luxury- bands- require- different- class- of- loyaltyprogram.html\#gs.t2FIWlg (Ac- cessed 23 December 17).

Shimul, A.S. , Lwin, M. , Phau, I. , 2016, Exploring the luxury brand attachment scale. In: Proceedings in Marketing in a Post-Disciplinary Era ANZMAC 2016, Christchurch, p. 517.

Sugiyono. 2017, Metode Penelitian Pendidikan Pendekatan Kuantitatif, Kualitatif, dan R\&D. Bandung: Alfabeta

Vigneron, F., Johnson, L.W., 2004, Measuring perceptions of merek luxury. J. Brand Manag, 11, 484506. https://doi.org/10.1057/palgrave.bm.2540194.

Daniel S. Soper, Ph.D., Calculator: Sobel Test For The Significance Of Mediation 4.0., www.danielsoper.com

Zeithaml, Valeria A., Bitner, Mary J., Gremler, Dwayne D. 2017, Services marketing : integrating customer focus across the firm, US :McGraw-Hill Education. 